\title{
Interconnected Power Systems with Superconducting Magnetic Energy Storage
}

\author{
Shinichi Nomura Member (Tokyo Institute of Technology, shin@nr.titech.ac.jp) \\ Takushi Hagita Non-member (Tokyo Institute of Technology) \\ Hiroaki Tsutsui Non-member (Tokyo Institute of Technology, htsutsui@nr.titech.ac.jp) \\ Yoshihisa SatoＭember (Daido Institute of Technology, satoy@daido-it.ac.jp) \\ Ryuichi Shimada Member (Tokyo Institute of Technology, rshimada@nr.titech.ac.jp)
}

Keywords: interconnected system, back-to-back, superconducting magnetic energy storage (SMES), helical coil, electromagnetic force

Electric power systems are usually interconnected with each other trough a back-to-back high-voltage direct-current (HVDC) link to increase reliability of electric power networks and to improve system operations. However, since the electric power has to be generated depending on the power demand, differences between peaks and valleys in the demand for the electric power are expected to be a serious problem in the future power systems.

The objective of this work is to discuss the concept of interconnected power systems with a Superconducting Magnetic Energy Storage (SMES) incorporated into a back-to-back DC link. Figure 1 illustrates a schematic diagram of the interconnected power system with the SMES. The SMES coils are connected in series between $\mathrm{AC} / \mathrm{DC}$ current source converters. In this case, each converter of the back-to-back system is used as a power conditioning system for the SMES coils.

This work improves this concept and proposes two-way switches (SW1, SW2) that can select the interconnected power systems. Since the AC/DC converter can be designed independently of the frequency of the power system, the two-way switch is connected to the AC side of each converter. By using the two-way switches, this system can provide the stored energy in the SMES system to each interconnected power system through two AC/DC converters. For instance, lower-cost power from the power network 2 can be stored through two converters during the off-peak hours and made available for dispatch to the power network 1 during periods of demand peak. Then this system increases the reliability of electric power networks and enables the economical operations depending on the power demand.

On the other hand, strong electromagnetic forces caused by high magnetic fields and coil currents are a serious problem in constructing SMES systems. To cope with this problem, the concept of Force-Balanced Coil (FBC) is applied to the SMES systems. The FBC is a helically wound hybrid coil of toroidal field coils and a solenoid. This coil can control the distribution of working stresses and minimize the required mass of the structure for induced electromagnetic forces by selecting an optimal number of poloidal turns per toroidal turn.

This paper describes the unique operations of the back-to-back interconnection with SMES and discusses the optimal SMES configuration that can reduce the cost of the superconducting coil by the effect of mass production.

Figure 2 shows the schematic illustration of the interconnected power system with 600-MWh class SMES. This back-to-back DC link system enables interchange of 300-MW power between the interconnected power systems and also SMES operation with the stored energy of $300 \mathrm{MW}-1.5$ hours. The required mass of the structure is proportional to the stored energy so that the 600-MWh SMES

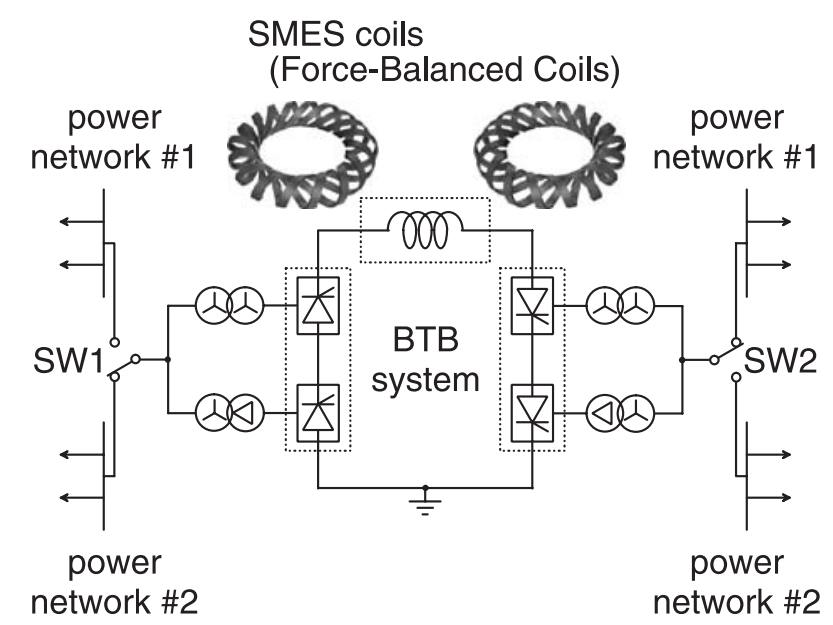

Fig. 1. Schematic diagram of the interconnected power systems with the SMES

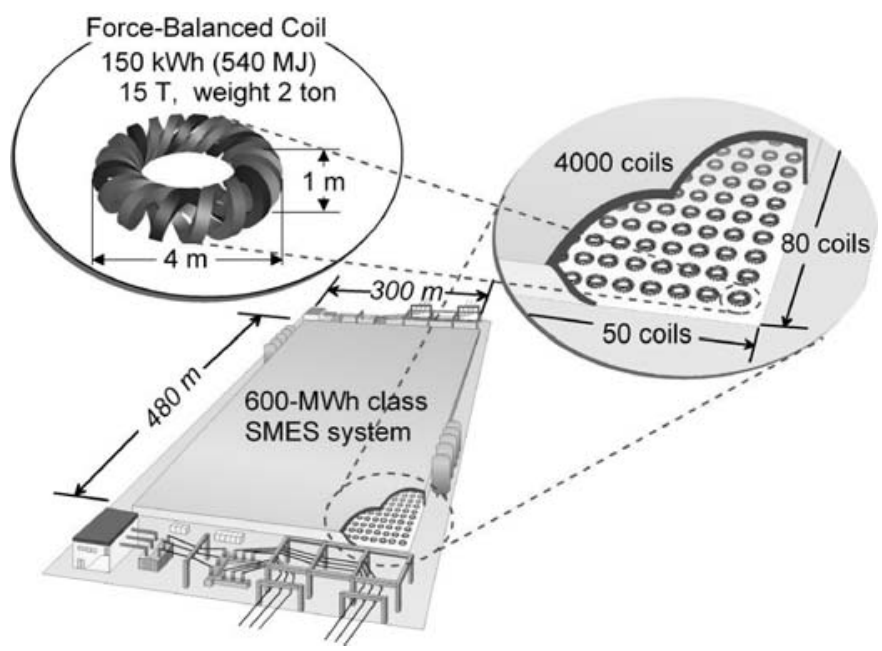

Fig. 2. Schematic illustration of the interconnected power systems with 600-MWh class SMES; This SMES is composed of 4000 superconducting coils; The stored energy of each coil is $540 \mathrm{MJ}(150 \mathrm{kWh})$

system is composed of $4000 \mathrm{FBCs}$ in order to reduce the cost of the superconducting coil by the effect of mass production. Each coil with an outer diameter of $4 \mathrm{~m}$ has 150-kWh stored energy at maximum magnetic field of $15 \mathrm{~T}$. This coil can reduce the required mass of the structure to $40 \%$ of that in the solenoid case. The dimensions of the SMES system will be $480 \mathrm{~m} \times 300 \mathrm{~m}$. 


\title{
超電導磁気エネルギー貯蔵付き系統間連系設備
}

\author{
正 員 野村 新一* 非会員 萩田 拓史* \\ 非会員 筒井 広明* 正 員 佐藤 義久** \\ 正員嶋田 隆一*
}

Interconnected Power Systems with Superconducting Magnetic Energy Storage

Shinichi Nomura*, Member, Takushi Hagita*, Non-member, Hiroaki Tsutsui*, Non-member, Yoshihisa Sato**, Member, Ryuichi Shimada*, Member

\begin{abstract}
The objective of this work is to discuss the concept of back-to-back interconnection systems with energy storage, especially with a Superconducting Magnetic Energy Storage (SMES) incorporated into a back-to-back DC link. In this case, each converter of the back-to-back system is used as a power conditioning system for the SMES coils. Since the $\mathrm{AC} / \mathrm{DC}$ converter can be designed independently of the frequency of the power system, a two-way switch is connected to the AC side of each converter. This two-way switch can select the interconnected power systems. By using the two-way switches, this system can provide the stored energy in the SMES system to each interconnected power system through two AC/DC converters. For instance, lower-cost power of each power network can be stored through two converters during the off-peak hours and made available for dispatch to each power network during periods of demand peak. Then this system increases the reliability of electric power networks and enables the economical operations depending on the power demand. This paper describes the unique operations of the back-to-back interconnection with SMES and discusses the optimal SMES configuration for a 300-MW class back-to-back interconnection.
\end{abstract}

キーワード : 系統間連系, BTB, 超電導磁気エネルギー貯蔵 (SMES), ヘリカルコイル, 電磁力

Keywords: interconnected system, back-to-back, superconducting magnetic energy storage (SMES), helical coil, electromagnetic force

\section{1. はじめに}

現在，電力の安定供給，電力設備の有効利用の観点から 電力会社間で電力を融通する送電網の強化が重要視されて いる。一般に, 交流系統間の連系方式として, 順・逆の交直 変換器を同一場所に設置する back-to-back（BTB）による 系統関連系方式が採用されている。系統間連系設備に電力 貯蔵機能を付加する方法として, BTB 方式の両変換器の直 流側に超電導コイルを直列接続し, 超電導磁気エネルギー 貯蔵（SMES）装置の機能を持たせる方法が検討されてい

\footnotetext{
* 東京工業大学 原子炉工学研究所

干 152-8550 東京都目黒区大岡山 2-12-1 N1-33

Research Laboratory for Nuclear Reactors, Tokyo Institute of Technology

N1-33, 2-12-1, O-okayama, Meguro-ku, Tokyo 152-8550

** 大同工業大学 電気電子工学科

干 457-8530 名古屋市南区滝春町 10-3

Department of Electrical Engineering and Electronics, Daido Institute of Technology

10-3, Takiharu-cho, Minami-ku, Nagoya 457-8530
}

る(1)(2)。そこで，本研究では，この概念を発展させ，BTB 方式の順・逆両変換器の交流側に連系する交流系統のいず れか選択可能な系統切替スイッチを設置し, 電力の需給状 況に応じた系統間の電力融通, 充電, 貯蔵, 放電動作の切 り替え運用が可能な SMES 機能付き系統間連系設備につい て検討する。

本論文では, SMES 機能付き系統間連系設備の構成と運 用方法を示し, 国内外の BTB 連系設備の運用状況から設 備の開発目標を明確にする。また, SMES 機能付き系統間 連系設備の概略設計を行い, 生産性の効率化と開発リスク の軽減化を期待する SMES 用超電導コイルの開発方針を検 討し, 設備の将来像を示す。

\section{SMES 機能付き系統間連系の構成と運用方法}

〈2・1 基本構成図 1 にSMES を付加した系統間連 系設備の構成を示す。図 1 に示すようにBTB 方式の順・逆 両変換器の直流側には超電導コイルを直列接続する。すな わち, BTB 方式の両変換器がそのまま SMES 装置の電源 として利用できる ${ }^{(1)(2)}$ 。BTB 方式の交直変換器は, サイリ 


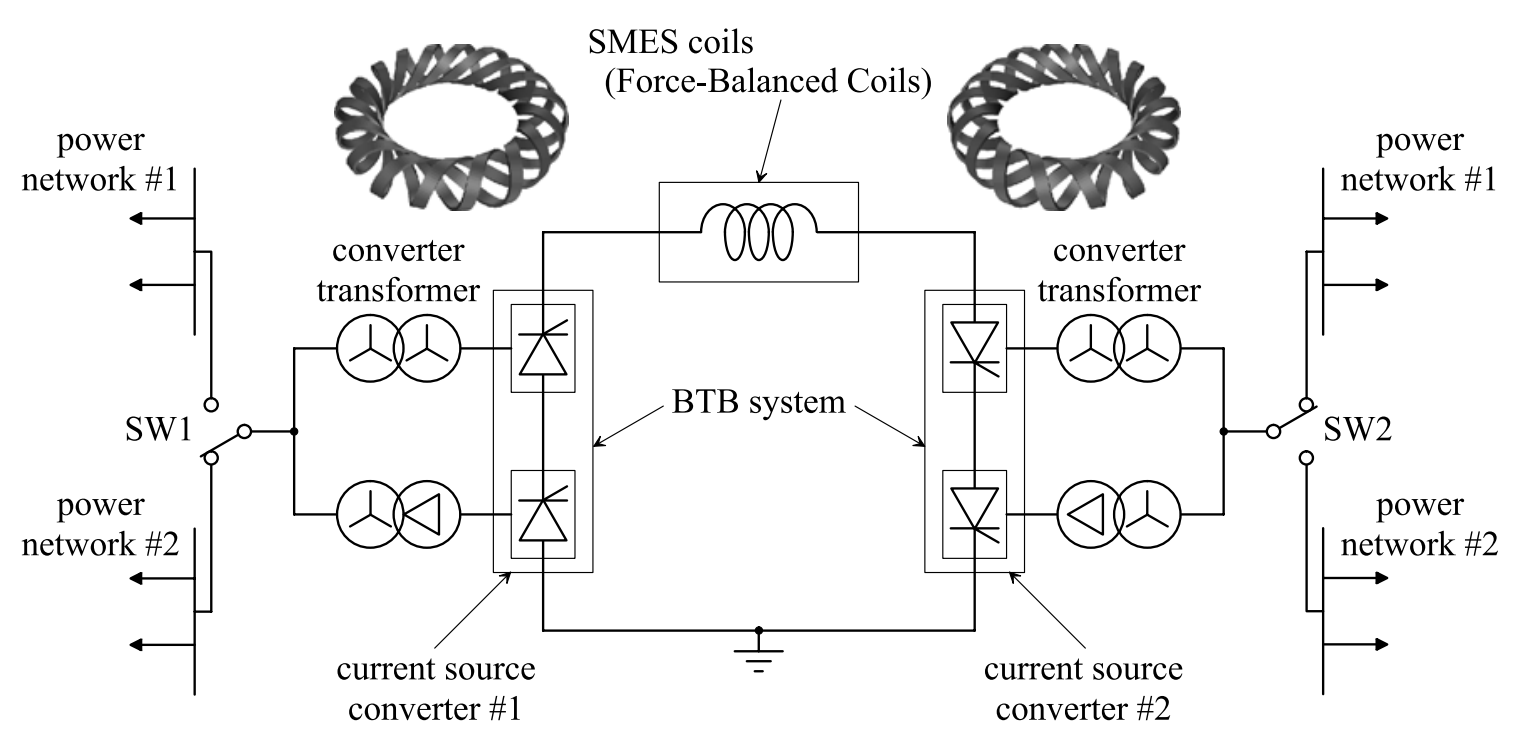

図 1 超電導磁気エネルギー貯蔵装置付き系統間連系設備の構成

Fig. 1. Schematic diagram of the interconnected power system with the SMES.

スタなど逆阻止能力を有する半導体電力変換素子で構成さ れた電流型変換器であり，電力系統における電流源として の機能を有する電力設備となる。

一方, BTB 方式による従来の系統間連系設備では, 通常 1 つの交直変換器に対して 1 つの交流系統が接続されている。 この場合，各交流系統から見た SMES 装置の入出力容量に 自由度を持たせることができない。そこで，交流系統の周 波数によらず交直変換器の設計は同じであることから, 図 1 に示すようにBTB 方式の順・逆両変換器の交流側には，そ れぞれ連系する交流系統のいずれか選択可能な系統切替ス イッチを設置する。この系統切替スイッチにより，BTB 方 式の交直変換器の利用率が向上する電力設備となる。

また，SMES 装置の大容量化を妨げている要因の一つで ある超電導コイルに働く電磁力の問題を解決するために, 後述する電磁力平衡コイル (FBC：Force-Balanced Coil) を 採用し，エネルギー貯蔵に必要な電磁力支持材量の最小化 を実現する ${ }^{(3)(4)}$ 。

〈2・2〉系統切替スイッチを用いた運用方法図 1 に 示すように，系統切替スイッチ SW1，SW2 をそれぞれ系 統 2 , 系統 1 に接続し, 系統 2 から系統 1 への電力融通を 行う場合を考える。この場合, 従来の系統間連系設備と同 じく, 変換器 1 を整流器動作, 変換器 2 をインバー夕動作 とし系統間の連系運用を行う。連系運用により直流電力回 路内に直流電流 $I_{\mathrm{d}}$ が流れると，自己インダクタンス $L$ を有 する超電導コイルの効果により,

$$
E_{\mathrm{m}}=\frac{1}{2} L I_{\mathrm{d}}^{2}
$$

の磁気エネルギー $E_{\mathrm{m}}$ が貯蔵される。すなわち, SMES 装 置を付加させることにより, 系統間の連系運用を行いつつ, 同時に SMES 運転を行うことが可能となる。
ここで，系統 2 の予備力が不足し系統間連系運用が維持 できない場合, 系統 2 側からの電力供給を遮断し, SMES 装置として電力を系統 1 へ供給する。さらに, 系統 1 の電 力需要が急増した場合, 系統切替スイッチ SW1 を系統 2 か ら系統 1 へ接続し, 両変換器を通じて SMES に蓄えられた 電力を系統 1 へ供給することも可能となる。すなわち, 系 統切替スイッチにより, 系統から要求される容量に応じた 運用ができ, 緊急融通時の信頼性を向上させることが可能 となる。

一方，待機運転時には，超電導コイルに所定の直流電流 を流した状態で，2つの変換器を制御角 $90^{\circ}$ 近傍での動作 またはバイパスペア動作とし，直流電流を循環させる。こ のとき, (1) 式で与えられる磁気エネルギーが超電導コイル に貯蔵され，SMES 運転が維持される。つまり，系統間の 連系運用を必要としない待機運転時においては SMES 装置 として運用でき, 設備全体の稼働率を高く維持することが 可能となる。

また, 夜間に系統 2 から電力を両変換器を通じて充電し, 昼間に系統 1 へ放電するなど, 系統間の時間的格差をつけ た連系運用なども可能となる。

\section{SMES 機能付き系統間連系の目標設備容量}

〈3・1〉 超電導コイル建設費返済期間の評価本節で は, SMES 機能付き系統間連系設備を昼夜間の日負荷平準 化用途として運用した場合に得られる利益から, 超電導コ イル建設費の返済年数を評価し，設備の貯蔵容量について 検討する。

図 2 は，実際に製作された超電導コイルおよび概念設計 に基づくコスト評価をまとめたものである ${ }^{(5)(6)}$ 。図 2 より， 超電導コイルの貯蔵エネルギーあたり単価は, 貯蔵エネル ギーの $-2 / 3$ 乗に比例している。このことから超電導コイ 


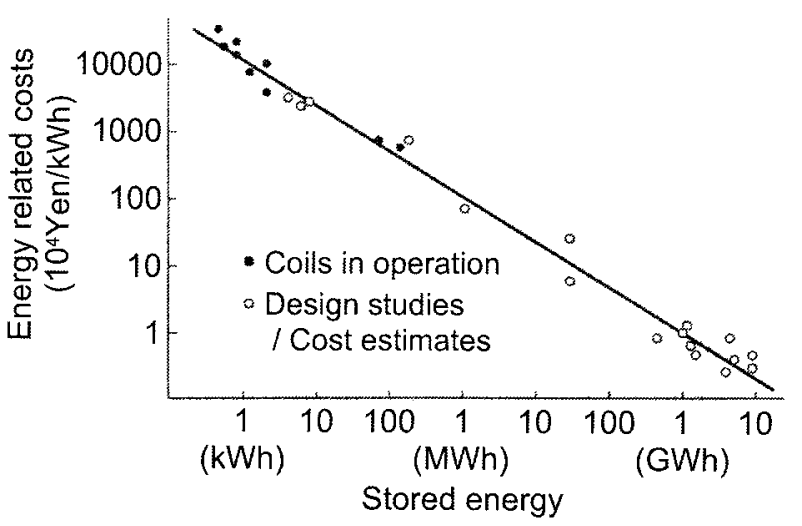

図 2 超電導コイルの貯蔵エネルギーあたり単価

Fig. 2. Energy related costs of the superconducting coils.

ルの建設費 $C_{\text {coil }}$ (億円) と貯蔵エネルギー $E_{\mathrm{m}}(\mathrm{MWh})$ との 関係を表す評価関数は,

$$
C_{\text {coil }}=10 E_{\mathrm{m}}^{1 / 3}
$$

と導出される。(2) 式より, 超電導コイルの建設費は貯蔵 エネルギーの $1 / 3$ 乗に比例し，貯蔵エネルギーに対するス ケールメリットを有する。図 2 に示すコスト評価の妥当性 に関しては，1 MWh 以上の大型超電導コイルの製作実績が ないため今後十分な検討を要するが，本研究では，将来的 に大規模 SMES 装置を経済的基盤に載せるために必要な超 電導コイルの開発目標コストとして捉え，(2)式で与えられ る評価関数を用いて議論を進める。

ここで，昼夜間の電力料金の格差を利用し, SMES 機能 付き系統間連系設備を日負荷平準化用途として運用した場 合に得られる利益に関して検討する。SMES 装置で利用す るエネルギー $E_{\mathrm{av}}$ は充放電率 $K$ を用いて

$$
E_{\mathrm{av}}=\kappa E_{\mathrm{m}}
$$

と表される。ここで, 充放電率 $\kappa$ とは超電導コイルの貯蔵 エネルギー $E_{\mathrm{m}}$ に対する利用エネルギー $E_{\mathrm{av}}$ との割合であ る。SMES で得られる単位電力量あたりの運用利益を $u_{\mathrm{e}}$ (円 $/ \mathrm{kWh}$ )とすると，設備の 1 日あたりの運用利益 $B_{\mathrm{e}}$ (万 円/日）は，

$$
B_{\mathrm{e}}=10^{-1} u_{\mathrm{e}} E_{\mathrm{av}}=10^{-1} u_{\mathrm{e}} \kappa E_{\mathrm{m}}
$$

となる。従って, 設備の年間運用日数を $D_{\mathrm{op}}$ (日/年) とし た場合，超電導コイルの建設費 $C_{\text {coil }}$ (億円）を日負荷平準 化で得られる運用利益 $B_{\mathrm{e}}$ (万円/日）で返済するのに要する 年数 $Y_{\mathrm{de}}$ (年) は,

$$
Y_{\mathrm{de}}=\frac{C_{\text {coil }}}{B_{\mathrm{e}} D_{\mathrm{op}}}=\frac{10^{6}}{u_{\mathrm{e}} \kappa D_{\mathrm{op}}} E_{\mathrm{m}}^{-2 / 3}
$$

より見積もることができる。

図 3 は, 超電導コイル建設費の返済期間と貯蔵エネルギー との関係を示している。ここでは, 単位電力量あたりの運用

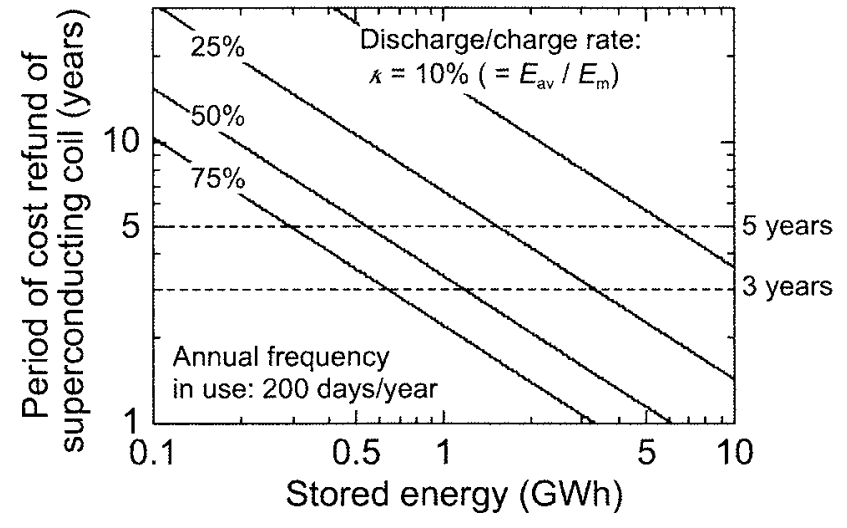

図 3 超電導コイル建設費の返済期間と 貯蔵エネルギーとの関係

Fig. 3. Period of the cost refund of the superconducting coil as a function of stored energy.

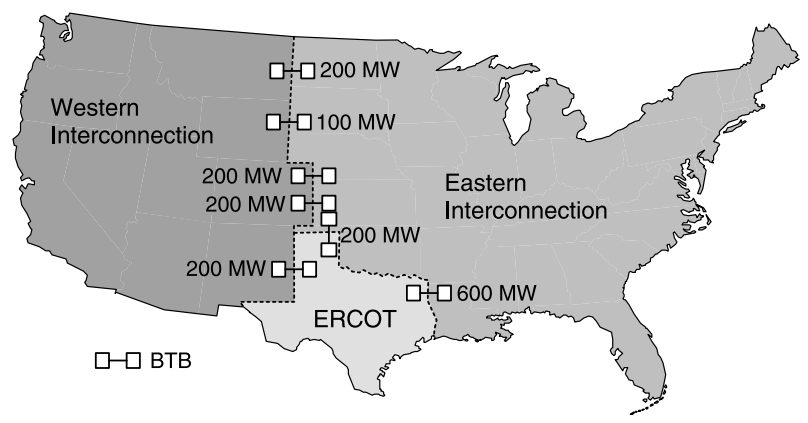

図 4 米国の系統間連系設備

Fig. 4. Interconnected power systems in USA.

利益を 30 円/kWh（昼間 35 円/kWh，夜間 5 円/kWh），設備 の年間運用日数を 200 日とした場合を例に超電導コイル建 設費の返済期間を算出した。図 3 より, 貯蔵エネルギーが大 きくなるほど, また充放電率が高くなるほど, 超電導コイル 建設費の返済期間が短縮されるのがわかる。例えば, 充放電 率が 75\%の場合，返済期間が $300 \mathrm{MWh}$ で 5 年，600 MWh で 3 年となり, 日負荷平準化の運用利益により, 系統間連 系設備に SMES 装置を付加させる効果を期待することがで きる。

BTB 方式による系統間連系設備に SMES 装置を付加さ せる技術は, 電力自由化市場の盛んな欧米諸国においても, その効果を期待することができる。例えば， 2003 年 8 月の オランダでは，通常 MWh あたり 15 60 EUR で取引され ている電力市場が，真夏の熱波で 8 月 11 日ごろから 3 日間 にかけて 10 倍の $600 \mathrm{EUR}$ にまで急騰した (7)。従って，電 力貯蔵装置を有する電力卸売業者が電力市場を制すること ができ，SMES 装置による運用利益を大いに期待できる。

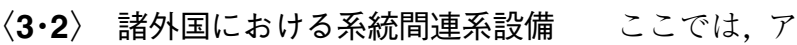
メリカおよび中国における系統間連系設備の運用状況, 計 画について述べる ${ }^{(8)}$ 。現在, アメリカでは, 四 4 に示すよう に, 位相の違う交流系統を連系させるために, 東部系と西部 


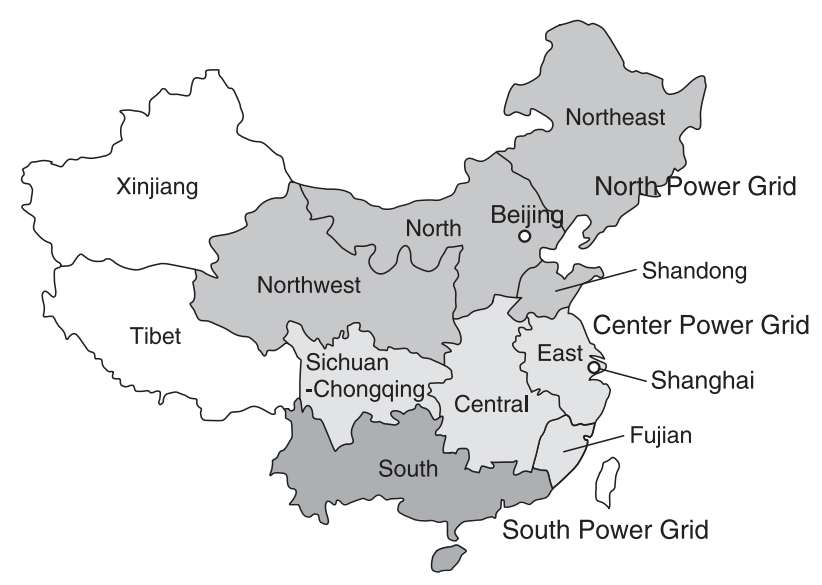

図 5 中国の電力系統地域

Fig. 5. Regional power systems in China.

表 $1600 \mathrm{MWh}$ 級超電導磁気エネルギー貯蔵装置 付き系統間連系設備の開発仕様

Table 1. Specifications of the interconnected power system with 600-MWh class SMES.

\begin{tabular}{lc}
\hline Rated power of the back-to-back DC link & $300 \mathrm{MW}$ \\
Voltage/Current & $6 \mathrm{kV} / 50 \mathrm{kA}$ \\
Stored energy of the SMES system & $600 \mathrm{MWh}$ \\
Available energy of the SMES system & $450 \mathrm{MWh}$ \\
Cycles of the SMES operation & 24 hours \\
Discharge duration time & 1.5 hours \\
\hline
\end{tabular}

系の間で 4 ケ所計 $700 \mathrm{MW}$, 東部系とテキサス系の間で 2 カ

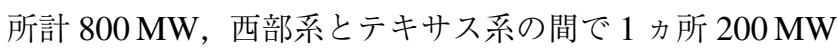
のBTBによる系統間連系設備が運用されている。

一方，中国の電力系統は，図 5 に示すように，山東，福 建，チベット，新疆のほか，東北，華北，西北，華東，華 中, 四川重慶抢よび南方の 7 つの地域別電力系統網から構 成されている(9)。将来的には，北部，中部，南部の 3 つの 送電網に統合し，直流送電や BTB による系統間連系運用 が計画されている( ${ }^{(8)(10)}$ 。

このように，世界的に系統間連系設備が運用・計画され ており，SMES 装置による連系強化を期待できる。特に， 中国の北京一上海間を SMES 装置を介して連系させること により送電網の強化が大いに期待できる。

$\langle\mathbf{3} \cdot 3\rangle$ SMES 機能付き系統間連系設備の開発目標 現 在，わが国に押いて 52 基-約 4600 万 $\mathrm{kW}$ の原子力発電所 が運転中（2002 年 3 月の調べ）である ${ }^{(5)}$ 。これに対して, 揚水発電所は 35 発電所, 総出力 2300 万 $\mathrm{kW}$ である ${ }^{(5)}$ 。仮 に，原子力発電所 1 基あたり平均 44 万 $\mathrm{kW}$ の揚水発電設 備が必要であると仮定すると，1 日 5 時間の負荷平準化を 行った場合， 220 万 $\mathrm{kWh}(2.2 \mathrm{GWh})$ の貯蔵エネルギーが 必要になるという計算になる。

一方, わが国の BTB 方式による連系設備は, 佐久間, 新 信濃 1 号機， 2 号機，東清水㧍よび南福光の 4 ヶ所 5 設備 で，300 MW を基本設備容量とし，総容量 $1500 \mathrm{MW}$ であ
る(11)。従って, 1 設備あたり 45 万 $\mathrm{kWh}(450 \mathrm{MWh})$ の電力 量を補償する SMES 装置を付加し系統連系を行った場合, 総容量 225 万 $\mathrm{kWh} \quad(2.25 \mathrm{GWh})$ を有する揚水代替規模の SMES 装置が実現できる。そこで, SMES 機能付き系統間 連系設備の開発目標を設備容量 $300 \mathrm{MW}$ とし, 超電導コイ

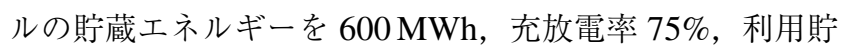
蔵容量 $450 \mathrm{MWh}$ と定め議論を進める。表 1 に開発仕様を まとめる。

超電導コイルの充放電率が $75 \%$ の場合, コイル電流值 は, (1) 式より最大電流值の半分まで低下する。従って, 設 備容量 $300 \mathrm{MW}$ に対してBTB 方式の 1 つの変換器あたり SMES の平均入出力容量は $150 \mathrm{MW}$ となるが, 系統切替又 イッチにより両変換器を用いた場合, SMES の入出力容量は $300 \mathrm{MW}$ まで利用可能となる。すなわち, 表 1 に示す仕様 は, 設備容量 $300 \mathrm{MW}$ での系統間連系運転と $300 \mathrm{MW}-1.5$ 時間分の SMES 装置とを兼ね備えた電力設備となる。

\section{600 MWh 級 SMES 装置付き系統間連系設備の 概略設計}

$\langle 4 \cdot 1\rangle$ SMES 用超電導コイルの開発方針 $\langle 3 \cdot 3\rangle$ 節 で述べた SMES 装置付き系統間連系設備の開発仕様をもと に $600 \mathrm{MWh}$ 級 SMES 用超電導コイルの概略設計を行う。 現在, 超電導コイルに働く電磁力の大きさがSMES 装置 の大容量化を妨げている大きな要因の一つとなっている。 特に大型の超電導コイルの場合, 岩盤支持などの開発リス クを伴う点が問題となる。超電導コイルの電磁力支持材の 質量 $M$ と貯蔵エネルギー $E_{\mathrm{m}}$ との関係は, 支持材の許容応 力 $\sigma_{\mathrm{a}}$, 支持材の密度 $\rho_{\mathrm{m}}$ を用いて,

$$
M=Q_{\max } \frac{\rho_{\mathrm{m}}}{\sigma_{\mathrm{a}}} E_{\mathrm{m}} \cdots
$$

と導出され，一般にエネルギー貯蔵に必要な電磁力支持材 量を議論する場合に用いられている(12)。ここで， $Q_{\max }$ と は, 最大発生応力に関する形状パラメータであり, 磁気工 ネルギーと支持材の体積で規格化された無次元パラメー夕 である。従って， $Q_{\max }$ の值を低減するためにコイル巻線形 状の最適化が重要となる。

図 1 に示した電磁力平衡コイルとは, ヘリカル巻線形状 のコイルであり, 最適なへリカル巻数を選定することによ り応力分布の均一化が達成され, 発生応力の最小化が実現 できるコイル方式である(3)(4)。(6) 式で与えられる $Q_{\max }$ の 值は, 電磁力平衡コイルの場合 0.5 となり, エネルギー貯 蔵に必要な電磁力支持材量をソレノイド $\left(Q_{\max }=1 \sim 2\right)$ の $1 / 2$ 以下にまで低減可能となる。

一方，(6) 式の関係から電磁力支持材の必要量 $M$ は貯蔵 エネルギー $E_{\mathrm{m}}$ に比例し, 貯蔵エネルギーに対するスケー ルメリットが得られないことがわかる。そこで，600 MWh 級 SMES 用超電導コイルの開発方針として, 輸送可能な大 きさの超電導コイルを多数個配置し, 生産性の効率化と開 発リスクの軽減化を期待する装置構成を考える。

本研究では, 超電導コイルの設計条件を以下のように定 


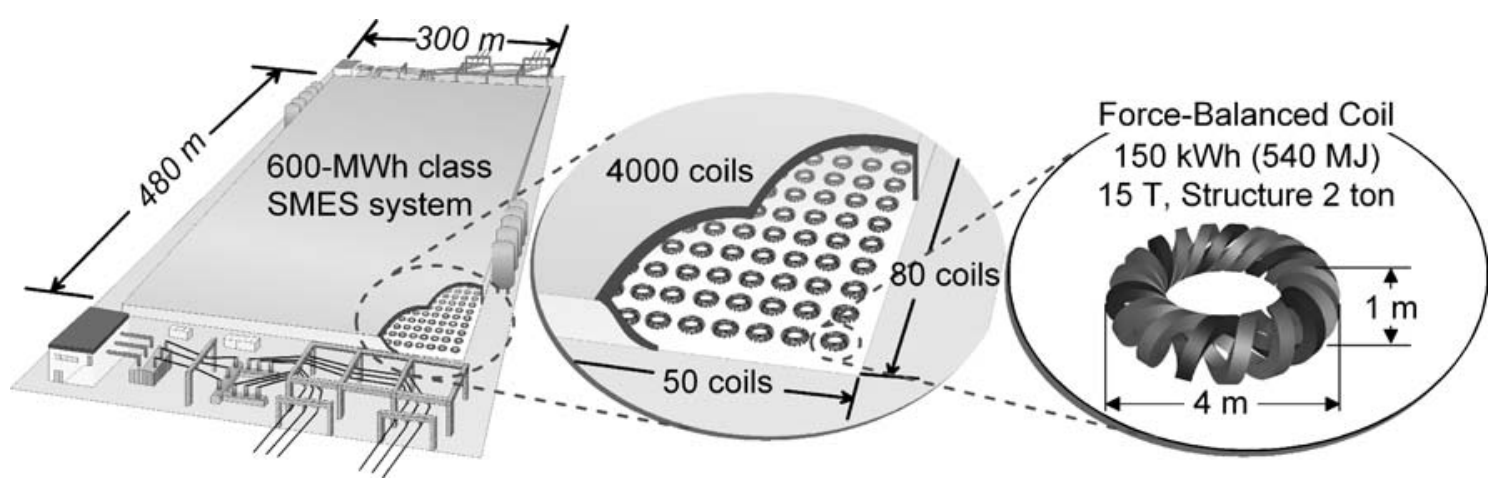

図 $6600 \mathrm{MWh}$ 級超電導磁気エネルギー貯蔵装置付き系統間連系設備の概観

Fig. 6. Schematic illustration of the interconnected power system with 600-MWh class SMES.

表 $2600 \mathrm{MWh}$ 級 SMES 用超電導コイルの 設計值

Table 2. Key parameters of the superconducting coils for the 600-MWh SMES system.

\begin{tabular}{lcc}
\hline & FBC & solenoid \\
\hline Stored magnetic energy $(\mathrm{kWh})$ & $150(540 \mathrm{MJ})$ & $\leftarrow$ \\
Magnetic field $(\mathrm{T})$ & 15 & $\leftarrow$ \\
Coil outer diameter $(\mathrm{m})$ & 3.9 & $\leftarrow$ \\
Coil height $(\mathrm{m})$ & 0.78 & 0.65 \\
Coil current $(\mathrm{kA})$ & 50 & $\leftarrow$ \\
Conductor length $(\mathrm{km})$ & 5.1 & 3.1 \\
Mass of the structure $\left(\times 10^{3} \mathrm{~kg}\right)^{*}$ & 1.8 & 4.9 \\
\hline
\end{tabular}

(* mass density: $8.0 \times 10^{3} \mathrm{~kg} / \mathrm{m}^{3}$, allowable stress: $\left.1200 \mathrm{MPa}\right)$

めた。

（1）現在，国際間協力で進められている国際熱核融合 実験炉（ITER）における超電導コイルシステムの 研究開発実績 ${ }^{(13)(14)} よ り ，$ 貯蔵エネルギーを $540 \mathrm{MJ}$ $(150 \mathrm{kWh})$ ，最大発生磁束密度を $15 \mathrm{~T}$ ，コイル電流 值を $50 \mathrm{kA}$ とする。

（2）超電導コイルの工場内製造性と現地までの可搬性 を重視し，コイル外直径を $4 \mathrm{~m}$ 以下とする。

超電導コイルの貯蔵エネルギーが $150 \mathrm{kWh}$ であるため, 上 記条件に基づく超電導コイルを 4000 個設置し, 貯蔵容量 $600 \mathrm{MWh}$ の SMES 装置を実現する。

〈4・2〉 $600 \mathrm{MWh}$ 級 SMES 用超電導コイルの設計 前 節で示した設計条件をもとに，600 MWh 級 SMES 用超電 導コイルの設計を行う。表 2 に電磁力平衡コイルの設計值 を同一規模のソレノイドと比較した結果を示す。ここで， 電磁力支持材の必要量は, 支持材の密度を $8.0 \times 10^{3} \mathrm{~kg} / \mathrm{m}^{3}$, 許容応力を $1200 \mathrm{MPa}$ として算出した。

表 2 の結果より, 電磁力平衡コイルで使用される $50 \mathrm{kA}$ 超電導導体は, ソレノイドに比べ 1.7 倍の長さが必要にな るが, 電磁力平衡コイルは電磁力支持材の必要量をソレノ イドの 40\%程度にまで低減させることが可能となる。よっ て, 電磁力平衡コイルは, SMES 用超電導コイルの軽量化 を実現するコイル方式として期待することができる。
表 2 に示す仕様の電磁力平衡コイルを 4000 個設置した $600 \mathrm{MWh}$ 級 SMES 装置の概観を図 6 に示す。貯蔵エネル ギー $150 \mathrm{kWh}$ の電磁力平衡コイルを縦に 80 個, 横に 50 個設置し, 貯蔵容量 $600 \mathrm{MWh}$ の SMES 装置を実現する。 このとき, SMES 装置の規模は, およそ $480 \mathrm{~m} \times 300 \mathrm{~m}$ と なる。

\section{5. まとめ}

交流系統間の連系方式として, SMES 装置の機能を備え た系統間連系設備に関して検討を行った。本設備の特徵は,

(1) BTB 方式の順・逆両変換器の直流側に超電導コイ ルを接続し, 待機運転時には SMES 装置として運用 することで設備全体の稼働率を高く維持することが できる。

(2) BTB 方式の両変換器の交流側に連系する交流系統 のいずれか選択可能な系統切替スイッチを設置する ことで BTB 方式の交直変換器の利用率が増加し, 緊 急融通時の信頼性を向上させることが可能となる。

(3) 系統切替スイッチの接続方法と変換器の動作方法 を適切に組み合わせることにより, 電力の需給状況 に応じた系統間の電力融通, 充電, 貯蔵, 放電動作 を切り替え運用することが可能となり，系統間の時 間的格差をつけた連系運用が可能となる。

という点にある。

国内外の BTB 連系設備の運用状況から, SMES 機能付 き系統間連系設備の開発目標を設備容量 $300 \mathrm{MW}$ での系統 間連系運転と $300 \mathrm{MW}-1.5$ 時間分の電力貯蔵機能とを兼ね 備えた電力設備と定め, $600 \mathrm{MWh}$ 級 SMES 用超電導コイ ルの概略設計を行った。本論文では,

（1）輸送可能な大きさの貯蔵エネルギー $150 \mathrm{kWh}$ (540 MJ) を有する超電導コイルを 4000 個設置す ることで, 生産性の効率化と開発リスク軽減化を期 待する SMES 装置の構成を示した。

（2）超電導コイル方式を電磁力平衡コイルとすること で，電磁力支持材の必要量をソレノイドの $40 \%$ 程度 にまで低減でき, 超電導コイルの軽量化が期待でき 


$$
\text { ることを示した。 }
$$

4000 個の超電導コイルから構成される $600 \mathrm{MWh}$ 級 SMES 装置の開発シナリオとして, BTB 方式の交直変換 器を多重化し, 毎年 $\mathrm{N}$ 個づつ超電導コイルを製作し順次運 用開始することでSMES 貯蔵容量を拡張する方法が考えら れる。今後は，設備全体の初期コストと運用コストを評価 し，装置実現に向けた詳細な検討を行っていく必要がある。 また, SMES 用電源としての低電圧大電流容量変換器のシ ステム構成の最適化と変換効率を評価するとともに, 超電 導コイルの製作容易性，漏洩磁界の低減化㧍よび冷却特性 を考慮に入れた最適なコイル形状と配置方法の検討を行っ ていく予定である。

(平成 16 年 10 月 25 日受付, 平成 17 年 7 月 15 日再受付)

\section{文献}

(1) K.-S. Tam and P. Kumar: "Application of Superconductive Magnetic Energy Storage in an Asynchronous Link between Power Systems", IEEE Trans. Energy Conversion, Vol.5, No.3, pp.436-444 (1990)

（2）関根聖治・樋口 登:「自律分散型超電導パワープールの提案」, 平成 5 年電気学会電力・エネルギー部門大会論文集（論文 II）, pp.255-256 (1993)

(3) H. Tsutsui, S. Nomura, and R. Shimada: "Application of Virial Theorem to Magnetic Confinement Fusion Device", J. Plasma \& Fusion Research, Vol.77, No.3, pp.300-308 (2001) (in Japanese)

筒井広明・野村新一・嶋田隆一：「Virial 定理の磁気閉じ込め核融合 装置への応用」, プラズマ・核融合学誌, 77, No.3, pp.300-308 (2001)

(4) S. Nomura, et al.: "Variations of Force-Balanced Coils for SMES", IEEE Trans. Appl, Superconduct., Vol.12, No.1, pp.792-795 (2002)

（5）嶋田隆一 監修，佐藤義久著：図説 電力システム工学 電気をつ くる・送る・ためる!, 丸善 (2002)

（6）新冨孝和：「中規模 SMES の設計」, 超電導エネルギー貯蔵シンポジ ウム’97, pp.71-76 (1997)

( 7 ) N. Bolt: "The Liberalized Electricity Market in the EU-Targets and Hurdles", IERE Central American Forum, S3-04, November 23-28, Costa Rica (2003)

(8) D. Povh and D. Retzmann: "Perspectives of Power System Interconnections", IERE Central American Forum, OP-03, Costa Rica (2003)

(9) F. Zhu, Y. Zheng, X. Guo, and S. Wang: "Environmental impacts and benefits of regional power grid interconnections for China", Energy Policy, Vol.33, pp.1797-1805 (2005)

(10) IEEJ Industry Applications Society News Letter, IEEJ Trans. IA, Vol.125, No.3 appendix, p.3 (2005-3) (in Japanese)

電気学会産業応用部門ニュースレター, 電学論 D, 125, 3, 付録, p.3 (2005-3)

(11）町田武彦 編集：直流送電工学パワーエレクトロニクス応用, 東京電 機大学出版局 (1999)

(12) Y.M. Eyssa: "Design of single layer superconductive energy storage magnets", J. Phys. D Appl. Phys., Vol.13, pp.1719-1726 (1980)

(13) C. Sborchia: "Status of ITER Magnet Design and Model Coils", IEEE Trans. Appl. Superconduct., Vol.10, No.1, pp.554-559 (2000)

(14) T. Terakado, et al.: "Pulse Operation Test of the ITER Central Solenoid Model Coil using the JT-60 Power Supply", Japan Atomic Energy Research Institute, JAERI-Tech 2001-056 (2001) (in Japanese)

寺門恒久, ほか：「JT-60 電源を用いた ITER 中心ソレノイドモデル コイルのパルス通電試験」, 日本原子力研究所 JAERI-Tech 2001-056 (2001)

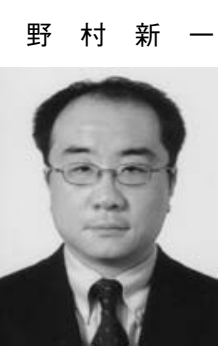

（正員） 1973 年 6 月 20 日生。1996 年 3 月明治 大学理工学部電気工学科卒業。2001 年 3 月東京 工業大学大学院博士後期課程修了。同年 4 月同大 学研究機関研究員, 2002 年 4 月から 2005 年 3 月 まで日本学術振興会特別研究員を経て, 同年 6 月 東京工業大学産学官連携研究員, 現在に至る。博 士 (工学)。主として電力工学, 超電導応用, 核 融合に関する研究に従事。IEEE 会員。

萩 田 拓 史 (非会員) 1980 年 7 月 9 日生。 2003 年 3 月大

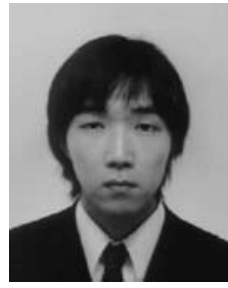
分大学工学部生産システム工学科卒業。2005 年 3 月東京工業大学大学院修士課程修了, 現在に至 る。主として超電導に関する研究に従事。

筒 井 広 明 (非会員) 1962 年 2 月 16 日生。1 989 年 3 月東

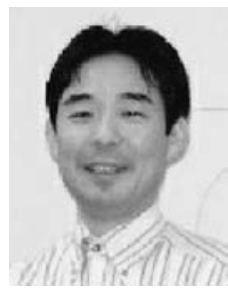
京大学大学院博士課程修了。同年 4 月日本原子力 研究所・那珂研究所，核融合特別研究生。同年 12 月東京工業大学工学部電気電子工学科助手。1990 年 12 月同大学原子炉工学研究所助手, 現在に至 る。工学博士。プラズマ物理, 核融合, 超電導応 用の研究に従事。日本物理学会, プラズマ・核融 合学会, 日本原子力学会, 日本応用数理学会会員。

佐 藤 義 久 (正員) 1950 年 4 月 21 日生。1 976 年 3 月東京

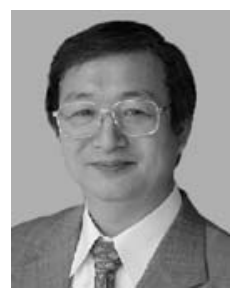
工業大学大学院修士課程修了。同年 4 月 (株) 東 芝入社。核融合装置, 加速器, 超電導応用装置の 技術開発に従事。1998 年 3 月東京工業大学大学 院博士課程修了。工学博士。2003 年 4 月大同工 業大学工学部電気電子工学科教授, 現在に至る。 電気学会論文賞, 著作賞受賞。現在, 小型風力発 電システム, 小型バイオマス発電等の再生可能工 ネルギーの実用化開発に従事。日本機械学会会員。

沜 田 隆 - (正員) 1948 年 1 月 31 日生。1975 年 3 月東京

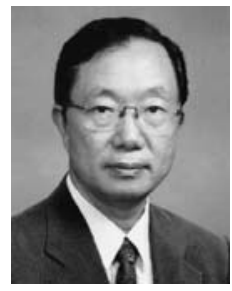
工業大学大学院博士課程修了。工学博士。同年, 日本原子力研究所入所, 大型卜カマク JT-60 核融 合装置の開発に従事。1 988 年 4 月東京工業大学工 学部電気電子工学科助教授, 1990 年 3 月同教授, 1990 年 5 月同大学原子炬工学研究所教授, 2005 年 10 月同大学統合研究院ソリューション研究機 構教授, 現在に至る。主として, 大電力システム, 電力工学, 電力貯蔵, パワーエレクトロニクス, 核融合炉工学, プラ ズマ制御の研究に従事。電気学会論文賞, 進歩賞, 著作賞受賞。 